\title{
Perceptions of Death and Recommendations for Suicide Prevention Policies: A Case Study of Suicide Case in Gunung Kidul
}

\author{
Muhammad Abdul Hadi* \\ Faculty of Science Education \\ Universitas Negeri Yogyakarta \\ Yogyakarta, Indonesia \\ muhammad0723fip2016@student.uny.ac.id*
}

\author{
Rahmatika Kurnia Romadhani \\ Faculty of Science Education \\ Universitas Negeri Yogyakarta \\ Yogyakarta, Indonesia \\ rahmatika@uny.ac.id
}

\begin{abstract}
Death is perceived differently among people from different cultures. These differences in perception stem from the variety of natural and physical context in humans' surroundings. Based on the existing theories, death is perceived as a matter that is difficult to accept. However, there has been an intriguing phenomenon that continuously occurred in Gunungkidul, Indonesia. Official records showed that Gunungkidul has the highest prevalence of suicide in Indonesia. Locals commonly refer to this phenomenon as pulung gantung. This phenomenon should be understood using contextual perspective. Existing theories on suicide and death have not been sufficient enough to explain the phenomenon that occurs in Gunungkidul. Therefore, this current research attempted to capture the suicide phenomenon in Gunungkidul using locals' perspective. This study used descriptive qualitative research method and indigenous psychology approach to examine this phenomenon. We used in-depth interviews to obtain data from seven informants. The results showed that locals residing in Gunungkidul perceive death as a form of transition from earth life to the afterlife. There are two attitudes of locals toward death: passive and active. These attitudes are achieved from the internalization of values from the local culture. Therefore, the choice to execute suicide by hanging is a caused a process of social learning. Based on these results, locals' perceptions of death should be considered when drawing suicide prevention policies in Gunungkidul.
\end{abstract}

Keywords-gunungkidul, indigenous Psychology, pulung gantung, suicide

\section{INTRODUCTION}

Death is the final stage of life that will inevitably be experienced by every human being. Perceptions of death vary depending on the values and cultural world views each may hold [1]. On the other hand, death itself is a taboo subject to converse in [2], let alone death when it occurs in the context of suicide.

Among the factors that influence perceptions of death are an individual's cultural and religious values, as well as spiritual orientation [3]. This is because beliefs that surround death are predominantly taught via spiritual teachings. This transcendental belief is seen as an effective manner of perceiving death as a meaningful experience for human beings [4].
Research on perceptions of death is not a novel topic, yet this is quite the opposite for the case that has and continues to occur in Gunungkidul, making it essential to re-examine the instances. In between 2015 - 2017, Gunungkidul was named the area with the highest suicide rate in Indonesia [5]. Moreover, there exists a myth known as pulung gantung which is described as a celestial object that resembles a blue long-tailed fireball. According to the beliefs of the local community, when there is a pulung gantung that passes or falls into one of the settlements, then one of the people who reside in the house will die of suicide [6].

It is important to note from the start that researchers of this study do not claim that locals' Gunungkidul perceives death differently. However, the researchers argue that locals who attempt suicide are considered a unique case which calls for further explanation in regards to local perception on the meaning of death.

In this study, cases of death by suicide in Gunungkidul were examined using the indigenous psychology approach which frames the research based on the society and its environment. Indigenous psychology emphasizes descriptive understanding of human function in its cultural context to highlight the problems from the perspective of an insider, based on his or her values and belief systems [7]. The cases of suicide in Gunungkidul is a unique problem that does not occur in other areas. Based on the data collected by Gunungkidul District Police, between 2001 2018, there have been 492 suicides in 18 sub-districts of Gunungkidul Regency. Most of the victims executed suicide by hanging themselves. An understanding of Gunungkidul citizens' perceptions of death is considered a necessary foundation to create appropriate interventions for suicide prevention policies in Gunungkidul.

\section{METHODS}

This research utilized descriptive qualitative methods and indigenous psychology approach to understand and describe the context of death by suicide in Gunungkidul. The indigenous psychology approach emphasizes the formation of meaning both from the side of informants and researchers so that the context of the problem as well as the culture becomes central to the analysis [8]. 
This study was based on taboo subjects; thus the selection of participants was predominantly based on the accessibility. Only informants who volunteered to participate were involved. The sample of this study consisted of seven residents who were of different ages and in different stages of life. The variation in age and stages of life is an essential factor in exploring possible differences. A sample that is too homogeneous makes it more challenging to discover nuances that could generate new knowledge or questions [9]. The researcher recruited the informants based on the recommendations of Rumah Sakit Umum Daerah (RSUD), Wonosari (Wonosari State Hospital), Gunungkidul. There was no relationship between the researcher and informants. The inclusion criteria were that each informant should be able to provide a narrowed focused and depth of experience.

All informants were local Javanese residents who came from Gunungkidul and had interacted with people before they conducted suicide. The seven informants were Javanese who were living in a high-context culture and resided in an area of Gunungkidul where suicide is predominant. The informants received written and oral information about the study and the term of confidentially. They subsequently provided written consents.

Data were collected via both structured and semistructured interviews. Data analysis used the Constant Comparative Method from Moleong [10], which comprises of the following steps: (1) reduction of interview data, (2) categorization, (3) synthesizing, and (4) compiling of working hypothesis.

The researcher assembled the data abstraction from the interviews of seven informants into units that would later be categorized in order to ease the data analysis process. Before categorizing, the researcher conducted the reduction of interview data to sort out parts of the interview verbatim that was relevant to the research question. This reduction process was followed by the process of coding to the relevant data. The researcher subsequently performed a synthesis, which was done to find the links between categories until it became incorporated into specific labels, illustrated in the table 1.
Table 1. Categories of Perceptions of Death in Gunungkidul

\begin{tabular}{|c|c|c|c|c|c|}
\hline \begin{tabular}{|c|} 
Code \\
$\begin{array}{c}\text { Informa } \\
\text { nts }\end{array}$
\end{tabular} & $\begin{array}{l}\text { Death is } \\
\text { a } \\
\text { Transitio } \\
\text { n to the } \\
\text { Afterlife }\end{array}$ & $\begin{array}{c}\text { Passive } \\
\text { Attitude } \\
\text { of } \\
\text { Suicide }\end{array}$ & $\begin{array}{c}\text { Active } \\
\text { Attitude } \\
\text { of } \\
\text { Suicide }\end{array}$ & $\begin{array}{c}\text { Suicide } \\
\text { by } \\
\text { Hanging }\end{array}$ & $\begin{array}{c}\text { Percepti } \\
\text { on of } \\
\text { Pulung } \\
\text { Gantung }\end{array}$ \\
\hline $\begin{array}{c}\text { Er: } \\
43 \text { years } \\
\text { old }\end{array}$ & $\begin{array}{l}\text { End of } \\
\text { life in the } \\
\text { world }\end{array}$ & Fate & - & $\begin{array}{c}\text { Imitating } \\
\text { someone } \\
\text { who had } \\
\text { previousl } \\
\text { y done it } \\
\text { in the } \\
\text { past }\end{array}$ & $\begin{array}{c}\text { A } \\
\text { fictitious } \\
\text { story } \\
\text { made by } \\
\text { locals }\end{array}$ \\
\hline $\begin{array}{c}\text { Sis: } \\
52 \text { years } \\
\text { old }\end{array}$ & $\begin{array}{l}\text { A move } \\
\text { to the } \\
\text { hereafter }\end{array}$ & - & Choice & $\begin{array}{c}\text { Has } \\
\text { heard of } \\
\text { a lot of } \\
\text { people } \\
\text { who have } \\
\text { done } \\
\text { suicide } \\
\text { by } \\
\text { hanging }\end{array}$ & An alarm \\
\hline $\begin{array}{c}\text { Pai: } \\
40 \text { years } \\
\text { old }\end{array}$ & $\begin{array}{l}\text { A move } \\
\text { to the } \\
\text { hereafter }\end{array}$ & $\begin{array}{l}\text { God's } \\
\text { secret }\end{array}$ & - & $\begin{array}{l}\text { Quick } \\
\text { death }\end{array}$ & $\begin{array}{c}\text { A cue for } \\
\text { death }\end{array}$ \\
\hline $\begin{array}{c}\text { Sir: } \\
36 \text { years } \\
\text { old }\end{array}$ & $\begin{array}{l}\text { Return to } \\
\text { God }\end{array}$ & - & Choice & $\begin{array}{l}\text { Accuracy } \\
\text { of death } \\
\text { is high }\end{array}$ & $\begin{array}{c}\text { A } \\
\text { fictitious } \\
\text { story } \\
\text { made by } \\
\text { locals }\end{array}$ \\
\hline $\begin{array}{c}\text { Lan: } \\
83 \text { years } \\
\text { old }\end{array}$ & $\begin{array}{c}\text { A } \\
\text { beginnin } \\
\text { g of a } \\
\text { different } \\
\text { life }\end{array}$ & Fate & - & $\begin{array}{c}\text { Imitating } \\
\text { someone } \\
\text { who had } \\
\text { previousl } \\
\text { y done it } \\
\text { in the } \\
\text { past }\end{array}$ & $\begin{array}{c}\text { Signal of } \\
\text { death }\end{array}$ \\
\hline $\begin{array}{c}\text { Jiw: } \\
\text { 30 years } \\
\text { old }\end{array}$ & $\begin{array}{l}\text { Death is } \\
\text { the separ } \\
\text { ate } \\
\text { between } \\
\text { the } \\
\text { physical } \\
\text { and } \\
\text { spiritual } \\
\text { spirit }\end{array}$ & $\begin{array}{l}\text { The fate } \\
\text { that can } \\
\text { no longer } \\
\text { be } \\
\text { prevented }\end{array}$ & - & $\begin{array}{l}\text { Pulung } \\
\text { gantung }\end{array}$ & $\begin{array}{l}\text { God's } \\
\text { sign }\end{array}$ \\
\hline $\begin{array}{c}\text { Did: } \\
18 \text { years } \\
\text { old }\end{array}$ & $\begin{array}{l}\text { End of } \\
\text { human } \\
\text { life and } \\
\text { the } \\
\text { beginnin } \\
\text { g of } \\
\text { another } \\
\text { life }\end{array}$ & - & Choice & $\begin{array}{c}\text { Easy to } \\
\text { do and } \\
\text { ropes are } \\
\text { available } \\
\text { everywhe } \\
\text { re }\end{array}$ & $\begin{array}{c}\text { Affirmati } \\
\text { on }\end{array}$ \\
\hline
\end{tabular}




\section{RESULT AND DISCUSSION}

\section{A. Death is a Transition to the Afterlife}

In general, all informants described death as having two concepts. First, death is interpreted as a time of life transition. In this case, the informants believe that human life is divided into two stages: earthly life and the afterlife. The process of death is a transition between earthly life to the afterlife. Second, death is the point of separation of the spirit from the mortal body. All informants believed that the human body consists of a spirit and a body, while death is the point that separates the two: the physical or mortal body can no longer be used to perform activities, but the spirit will still live in another existence.

The belief that death is the transition to life in the hereafter is rooted in the cultural concept of the individual's dwelling [11]. Someone who grows up and continues to be taught that there is another life (hereafter) will have the belief that death is not the end of human existence. Moreover, a Selametan ceremony (communal feast) is held after a person's death as a form of sending prayers to "those who have died" [12], indicating the belief that individuals will continue to live after death. Lan, 83 years old, said that:

We have (go through) two stages of life. There are the earth life and afterlife. Death is merely the end of earth life but the beginning of the afterlife.

The perception that death is a transition to another life is a belief that is deeply rooted within the Javanese society. Layangkuning states that among Javanese people, death is interpreted as an attempt to return to the beginning of existence (sangkan paraning dumadi), hence the symbol of human life (mortal body) is released and abandoned to move to another life (hereafter) [13]. Jiw, 30 years old, expressed his thought that:

Death is a separation between the physical and spiritual spirits. Hence humans are composed of two things: physicality and spirituality. So when a person dies, that is the separation between the physical and spiritual spirits.

According to Samad [14], Jiw's view that human beings have both a body and a spirit relates to an individual's spiritual beliefs. Death is considered a separation between the mortal body and the eternal spirit towards another existence [15]. Informants' perception of death cannot be separated from the concept of Eastern culture which emphasizes the mutual coexistence and interdependence of life and death [16]. Therefore, death is not perceived as the end of life but as mutually intact and related to human existence.

\section{B. Attitudes of Suicide in Gunungkidul}

In connection with the suicide deaths that occurred in Gunungkidul, informants had two different attitudes. First, a passive attitude which interprets that death is God's predetermined fate, thus there is no human intervention in the process of dying. Suicide is believed to be the will and destiny that God has set for human beings. Second, an active attitude, which assumes that death is a human's choice. Suicide is considered as a route to death that is deliberately chosen by suicide perpetrator.
The notion of the passive attitude of suicide was based on one characteristic of negative religious coping. Smith, Pargament, Koenig, and Perez [17] pointed out that the person who used deferring religious coping will passively wait for God to control the situation. When the pattern of "negative religious coping" appear, persons who consider religion significant might experience an increase in suicide risk [18].

On the other side, the active attitude of suicide comes from the libertarian perspective. This perspective states that suicide can be a carefully contemplated decision, often rationalized as a reasonable response to avoid pain or suffering [19]. Libertarians value freedom of choice and the decision to die by suicide is a right and rational choice. However, if the informants look at suicide with an active attitude, then this perspective related to the illusion of conscious choice. Active attitude needs decision making, which requires a balance between deliberative and effective processes. Active attitude toward suicide negates that if individuals are unable to consider the emotional aspects and cognitive biases that occur, their decisions will be impaired, especially in the case of suicide [20], for instance, depression is a significant factor in suicide in Gunungkidul [21]. Depression decreases cognitive flexibility and distorts the affective abilities of sufferers [22], which leads the decision-making of depression sufferers to become biased and unbalanced. Based on this view, suicide under depression is no longer considered an individual's conscious choice.

\section{1) Passive Attitude of Suicide}

In this study, four informants perceived death with a passive attitude. The passive attitude here means that the individual has no power over death. A passive attitude is born from the Javanese culture, which believes that human life is defined by fate. Everything that happens is a provision of fate that must be humbly accepted or legawa [23], including acceptance of death as Jiw said:

Death has always been God's secret. Besides that, indeed, living humans must die. That has always been (one of the) connection between God and humans. We live because there is (God) who gives life, then we will return (to God) again. We cannot know about death, we don't even know when we will die, in what way - we also don't know, that includes what we previously mentioned about (the case of) self-hanging in Gunungkidul. (It is) also one of those things we don't know what will cause us to face sudden death, suddenly die.

Another informant, Pai (40) considers suicide as fate and predetermined provision of God so that humans should not interfere with it. This perspective makes self-hanging behavior in line with Javanese cultural logic of resignation and acceptance of all the situations. The people of Gunungkidul accept this way of death and consider it natural because it is fate that is outside their intervention [24].

The view that suicide is God's destiny is related to one characteristic of negative religious beliefs. Xie, Chen, Pan, Tao, Li, Zhang, and Ye [25] found that hospital patients in 
China who have religious beliefs are at a higher risk of having suicidal thoughts relative to patients who are not religious. Religious belief related to negative coping sees that tragedies experienced by individuals are considered as a form of God's punishment and blame, which leads to feelings of being abandoned [26]. Those who consider religion very important and use "negative religious coping" are riskier to have suicidal attempts [27].

According to Karim [23], the concept of resignation to fate is a form of the tools of surrendering to God. This resignation and attitude of surrender are characterized by a person's manner of acceptance when facing difficulties. The concept of resignation contradicts with Western assumptions of self-defense mechanisms in the form of selfserving bias mentioned by Myers [28]. Myers stated that individuals tend to attribute distress to external factors outside of themselves while attributing success to themselves. However, this is different from assumptions of the Eastern culture, where Ratih and Tobing [29] found that suicide offenders resign themselves and try to accept their life as is.

In the Javanese context, there exists a term called mawas diri, which means that individuals should introspect what they have done [30], which includes looking closely at their situation to find out the cause of their suffering. Suffering and distress experienced by an individual are considered to be a gift from God that must be acknowledged with acceptance, thus if the problem one faces feel burdensome and is beyond one's capacity, suicide is then seen as an alternative solution of accepting (nrima) God's trials. Jiw, 30 years old, stated that:

If indeed the problem is burdensome and there is no way out, (I think) it is not a problem if (a person sees) suicide as a solution.

Jiw's views on suicide as an alternative solution is a form of helplessness. Wenzel, Brown, and Beck [31] stated that helplessness is a belief that the future looks scary and the problems a person faces no longer have a way out. A meta-analysis study conducted by Valentina and Helmi [32] showed that there is a strong correlation between helplessness and suicidal behavior.

\section{2) Active Attitude of Suicide}

Three informants of this study perceived death with an active attitude. The active attitude comes from informans' view that everything humans experience is a result of their freedom of choices. Thus a person is free to want and accept the consequences of their choices, including death. Death by suicide is seen as a free will that is the conscious decision of the suicide perpetrators [33], as well as a form of escapism from the real problem at hand [34]. Sis (52 y.o) stated that:

Death is a certainty, but the manner of death is a

choice. Whether that choice is a success or not,

part of it is our will which I mentioned earlier.

Sis's belief that every human being has a freedom of action is in line with the foundation of Jean-Paul Sartre's existentialism, which states that the human self has a healthy and rational mind in determining decisions, including in suicide decisions [35].

This philosophical view which states that suicide is a conscious and rational decision excludes other factors such as the victim's mood, circumstances, and individual differences. A study by Deisenhammer, Schmid, Kemmler, Moser, and Delazer [36] found that patients who commit suicide attempts often make risky decisions. Shanker and Bachle [37] added that the absence of consideration of other aspects makes the decisions taken by suicide perpetrators unbalanced and biased.

\section{Hanging as a Suicide Method in Gunungkidul}

Among the methods of suicide that took place in Gunungkidul, the choice of death by hanging was the most frequently used. Between 2015-2017, Andari [5] stated that $91 \%$ of the victims chose the method of death by hanging. One of the informants, Sis (52) considered that death by hanging was a very successful method so it was likely to be chosen as he said:

(Suicide by) hanging, in my opinion, is the easiest way to die. It is the cheapest too and that may also be, because, maybe (the perpetrator) had wishful thinking, then hang him or herself in the manner that is common in Gunungkidul, and there are also many who say, say the success rate is high.

The almost uniform method of death shows the pattern of death that Sis believed is easy and successful in claiming individual lives. The success of this suicide method can spread and lead to suicidal thoughts for others who are at similar risks of suicide [38]. This is related to cultural mechanisms that underlie the outspread of suicide. The similarity of methods can serve as a "guide" for individuals who want to end their lives. A particular type of suicide stories triggers one type of suicide [39], including information of hanging one's self as a choice of death.

The idea of suicide by hanging may be obtained from social learning. Practical information about how to commit suicide (for example, using slap straps to hang one-self, commit crimes, or complete suicide) is acquired through social learning [40]. Detailed and repeated information related to suicide can normalize this behavior. The effects of spreading suicide information can then be imitated, leading to ideas regarding suicide [41], including the use of hanging methods. Pai (40 y.o) said that:

So, indeed, hanging (yourself) is the most potent way to die in Gunungkidul. Besides, it seems like taking medicine and so on, it seems like it does not necessarily (guarantee) death, so just copy (what has been done successfully in the past) if you want to die quickly, that is, by hanging yourself.

Darmaningtyas [42] states that a large proportion of the population of Gunungkidul who work as farmers and fishermen are familiar with rigging, thus hanging is a method of death that is easy to imitate. Slap straps that are often used as suicide tools are readily available, thus suicide by hanging is an easy and economical death choice for the people of Gunungkidul as Did (18 y.o) told:

Those who hang themselves work as farmers, gardeners, (and) fishermen use rope because I think it is part of the equipments they use daily. It is used in their (line of) work. You don't have to buy poisons, or any other tools. 
The choice of tools one uses for suicide is related to one's accessibility to dangerous objects. Pardede [43] conducted a study of tools that are often used for suicide and found that dangerous objects or substances that are affordable are often used to end lives. Therefore, the affordability of rigging for the Gunungkidul community makes it a common tool for suicide. Moreover, according to Paiman's statement, hanging is the deadliest way to deliver one to their death.

\section{Perception towards Pulung Galung}

Pulung gantung is a cultural belief in Gunungkidul that has always been associated with suicide. According to Fahrudin [44] pulung gantung is a bluish red ray at night that swiftly flashes through the sky. In any case, where the object appears and falls somewhere, there will soon be a suicide.

The belief that pulung gantung is a sign of death is still believed by some residents of Gunungkidul. Three informants of this study perceived that pulung gantung plays a role in causing suicide as Did said:

Pulung gantung is a contributing factor to suicide, (but) there (already) exists severe problems and suicidal thoughts. Then comes pulung gantung, it's a sign that the solution to the problem is just hanging him or herself.

Didi's attribution of pulung gantung as one of the causes of suicide can be seen as a form of external locus of control. External locus of control is the belief that there are specific reinforcers that control life or a person's behavior which may take the form of luck, fate, destiny, and things that are beyond the control of individuals [45, 46, 47, 48]. Saied, Aal, and Mahmoud [49] also stated that there is a strong correlation between external locus of control and suicide.

Pulung gantung is a mythical cultural belief which continues to be believed by some residents of Gunungkidul as something that has control over someone committing suicide. According to Suwena [50], pulung gantung is considered a legitimacy of suicide in Gunungkidul.

\section{RECOMMENDATIONS FOR SUICIDE PREVENTION POLICIES}

The result of this study facilitates a deeper understanding of the different perceptions of death in an environment where suicide cases have taken place. There are two recommendations for suicide prevention that can be considered. First, positive assistance and counseling on religious coping. Second, the postulation of standards for suicide coverage in the mass media.

Positive understanding of religious coping may be associated with less psychological distress [51], including a decrease in the risk of having suicidal ideas. At present, the government of Gunungkidul has issued Decree Number 121/KPTS/TIM/2017 concerning the Establishment of a Suicide Prevention Team (Tim Penanggulangan dan Pencegahan Bunuh Diri) to reduce the number of suicides in Gunungkidul.

This research found that some religious characteristics related to individual perceptions of death may increase the risk of suicide. Therefore, several teachings related to fate, self-submission, and feelings of guilt must be reinterpreted into positive religious coping. This understanding can contribute through the assistance and outreach carried out by the Suicide Prevention Team of Gunungkidul.

Suicide in Gunungkidul has also occurred through the process of social learning. One of the most accessible social learning tools that the government should utilize is mass media. Detailed mass media coverage regarding suicide in Gunungkidul may shape a person's mindset and lead to modeling if he or she finds that the person who attempted suicide was in a similar condition and had the same problems [52]. So far, World Health Organization has published guidelines for the media in regards to suicide broadcast [53], but until now, there has been no specific guide on suicide reporting for Indonesian journalists. Researchers of this study also have not found any studies on the effects of excessive suicide reporting and suicides that have occurred in Indonesia. However, Sisask and Varnik [54] stated about the possibility of a relationship between the types of media reports on suicide and forms of suicide imitation. Therefore, it is necessary to formulate a policy on mass media coverage related to suicide, especially for suicide cases in Gunungkidul.

\section{CONCLUSION}

This study aimed to gain a deeper understanding and knowledge about the perceptions of death in the environment where suicide cases have taken place, as well as people's belief in pulung gantung in Gunungkidul. The results of this study indicate that the informants' perception of death is a transition between earth life towards the afterlife. For all informants, human existence consists of both a body and spirit in which death is a separation between the two.

Regarding cases of death by suicide, informants have two different attitudes: passive and active. The passive attitude is related to negative religious coping, which leads to resignation and helplessness, while active attitudes are related to unbalanced and biased decision making. Pulung gantung is seen as an external locus of control, meaning that an external factor controls the action of suicide. Suicide by hanging is chosen based on social learning from the environment as well as through over-exposure from past suicide cases that occurred in one's community. The results of this study should be considered to recommendations for suicide prevention policies in Gunungkidul.

\section{ACKNOWLEDGMENT}

The authors are thankful to Banyu Wicaksono, M.Sc., Psycholoog. and Dr. Rita Eka Izzaty, S.Psi., M.Si., Psikolog., Head of Psychology Program, Faculty of Science Education, Universitas Negeri Yogyakarta, for the providing the necessary facilities of the paper. 


\section{REFERENCES}

[1] J. Gire, "How death imitates life: cultural influences on conceptions of death and dying," Online Readings in Psychology and Culture, Vol. 6, December 2014.

[2] E. S. Prater, Perceptions of death and the effects of emotion, McKendree University: Illinois, 2009

[3] P. Pentaris, "Culture and death: a multicultural perspective," Hawaii Pacific Journal of Social Work Practice, Vol. 4, pp. 45-84, May 2011.

[4] J. Dezutter, B. Soenens, K. Luyckx, S. Bruyneel, M. Vansteenkiste, and B. Duriez, and D. Hutsebaut, "The role of religion in death attitudes: distinguishing between religious belief and style of processing religious contents," Death Studies, Vol. 33, pp. 73-92, February 2009.

[5] S. Andari, "Fenomena bunuh diri di Kabupaten Gunungkidul (Suicide phenomenon in Gunungkidul)," Sosio Konsepsia. Vol. 7, pp. 92-107, December 2017.

[6] W. Gamayanti, "Usaha bunuh diri berdasarkan Teori Ekologi Bronfenbrenner (Suicide attempts based on Bronfenbrenner's Ecological Theory)," Psympathic: Jurnal Ilmiah Psikologi, Vol. 1, pp. 204 - 230, June 2014

[7] L. N. Hakim, "Ulasan konsep: pendekatan indijinus (Concept review: the indigenous approach)," Jurnal Aspirasi, Vol. 5, pp. 165-172, December 2014.

[8] Faturochman, M. W. Minza, and T. A. Nurjaman, Memahami dan mengembangkan indigenous psychology (Understanding and depeloping indigenous psychology, Yogyakarta: Pustaka Pelajar, 2017.

[9] K. Malterud, Qualitative methods in medical research: an introduction, Oslo: Universitetsforlaget, 2011.

[10] L. J. Moleong, Metode penelitian kualitatif (Qualitative research methodology). Bandung: Rosdakarya, 2010.

[11] R. W. Bibby, "Life after death," Studies in Religion/Sciences Religieuses, Vol. 46, pp. 130-141, July 2016.

[12] Suwito, A. Sriyanto, and A. Hidayat, "Tradisi dan ritual kematian wong Islam Jawa (The tradition and ritual of the death of javanese moslem)," Jurnal Kebudayaan Islam, Vol. 13, pp. 197-216, July 2015.

[13] B. Layangkuning, B, Sangkan paraning dumadi orang Jawa dan rahasia kematian (Sangkan Paraning Dumadi javanese and the secret of death), Yogyakarta: Penerbit Narasi, 2013.

[14] S. A. A. Samad, "Konsep ruh dalam perspektif psikologi pendidikan Barat dan Islam (The concept of spirit in the perspective of Western and islamic educational psychology)," Fenomena, Vol. 7, pp. 215 228, 2015.

[15] A. M. Bhat, "Human psychology (fitrah) from islamic perspective," International Journal of Nusantara Islam, Vol. 4, pp. 1-74, 2016.

[16] L. A. Harvell and G. S. Nisbett, Denying death: an interdisciplinary approach to terror management theory, London: Psychology Press, 2016.

[17] K. I. Pargament, B. W. Smith, H.G. Koenig, and B. Perez, "Patterns of positive and negative religious coping with major life stressors,' Journal for the Scientific Study of Religion, Vol. 37, pp. 710-724, January 1998.

[18] R. E. Lawrence, D. Brent, J. J. Mann, A. K. Burke, M. F. Grunebaum, H. C. Galfalvy, and M. A. Oquendo, "Religion as a risk factor for suicide attempt and suicide ideation among depressed patients," The Journal of Nervous and Mental Disease, Vol. 204, pp. 845-850, November 2016.

[19] A. O. Ho, "Suicide: rationality and responsibility for life," Canadian Journal of Psychiatry, Revue Canadienne de Psychiatrie, Vol. 59, pp. 141-147, March 2014.

[20] K. Szanto, W. B. de Bruin, A. M. Parker, M. N. Hallquist, P. M. Vanyukov and A. Y. Dombrovski. "Decision-making competence and attempted suicide," The Journal of Clinical Psychiatry, pp. e1590 e1597, December 2015.

[21] F. Tentama, S. A. Mulasari, T. S. Sukesi, and Sulistyawati, "Penyuluhan dan pendampingan pada korban selamat percobaan bunuh diri di Gunung Kidul (Counseling and assistance to survivors of suicide attempts in Gunung Kidul)," International Journal of Community Service Learning, Vol. 3, pp. 27-32, January 2019.

[22] J. D. Caouette and A. E. Guyer, "Cognitive distortions mediate depression and affective response to social acceptance and rejection," Journal of Affective Disorders, Vol. 190, pp. 792-799, January 2016.

[23] A. Karim, "Makna kematian dalam perspektif tasawuf (The meaning of death in the perspective of sufism)," Esoterik, Vol. 1, pp. 21-46, June 2015.
24] M. Kumalasani, "Latar Belakang Pelaku Gantung Diri di Kecamatan Wonosari (The background of the suicide perpetrators by hanging in district Wonosari)," Universitas Islam Negeri Sunan Kalijaga, Yogyakarta, Unpublished theses, 2018.

[25] L. F. Xie, P. L. Chen, H. F. Pan, J. H. Tao, X. P. Li, Y. J. Zhang, and D. Q. Ye, "Prevalence and correlates of suicidal ideation in SLE inpatients: Chinese experience," Rheumatology International, Vol. 32, pp. 2707-2714, September 2012.

[26] P. Stratta, C. Capanna, I. Riccardi, C. Carmassi, A. Piccinni, L. Dell'Osso, and A. Rossi, "Suicidal intention and negative spiritual coping one year after the earthquake of L'Aquila (Italy)," Journal of affective disorders, Vol. 136, pp. 1227-1231, February 2012.

[27] D. S. Molock, R. Puri, S. Matlin, and C. Barksdale, "Relationship between religious coping and suicidal behaviors among African American adolescents," The Journal of Black Psychology, Vol. 32, pp. 366-389, August 2006.

[28] D. G. Myers, Social psychology, New York: McGraw-Hill, 2010.

[29] A. S. W. Ratih and D. H. Tobing, "Konsep diri pada pelaku percobaan bunuh diri pria usia dewasa muda di Bali (Self-concept on suicide perpetrators of young adult in Bali)," Jurnal Psikologi Udayana, Vol. 3, pp. 430-444, November 2016.

[30] A. W. Irawan and D. Lagensari, "Mawas diri kawruh jiwa sebagai teknik psikoterapi untuk mengurangi bullying pada siswa (Mawas diri kawruh jiwa as psychotherapy techniques to reduce bullying in students)," Prosiding Seminar Bimbingan dan Konseling. Vol 1, pp. 57-66, April 2017.

[31] A. Wenzel, G. K. Brown, and A. T. Beck, "Cognitive therapy for suicidal patients: scientific and clinical applications," Washington, DC, US: American Psychological Association, 2009.

[32] T. D. Valentina and A. F. Helmi, "Ketidakberdayaan dan perilaku bunuh diri: meta-analisis (Helplessness and suicide behavior: metaanalysis)," Buletin Psikologi, Vol. 24, pp. 123-135, 2016.

[33] S. Marliana, "Bunuh diri sebagai pilihan sadar individu": analisa kritis filosofis terhadap konsep bunuh diri Emile Durkheim ("Suicide as an individual conscious choice": philosophical critical analysis of the concept of suicide Emile Durkheim). Faculty of Science and Culture: Universitas Indonesia, Depok, Unpublished theses, 2012.

[34] I. Rochmawati, Nglalu: melihat fenomena bunuh diri dengan mata hati (Nglalu: Seeing the suicide phenomenon with the conscience), Yogyakarta: Jejak Kata Kita, 2009.

[35] N. Burton, Growing from Depression, Morrel Ave: Acheron Press, 2017.

[36] E. A. Deisenhammer, S. K. Schmid, G. Kemmler, and B. Moser, and M. Delazer, "Decision making under risk and under ambiguity in depressed suicide attempters, depressed non-attempters and healthy controls," Journal of Affective Disorders, Vol. 226, pp. 261-266, January 2018

[37] S. Shanker and S. Bakhle. "The Role of decision-making in suicidal ideation," Acta Psychopathology, Vol. 4, March 2018.

[38] R. D. Baller and K. K. Richardson, "The 'dark side' of the strength of weak ties: the diffusion of suicidal thoughts," Journal of Health and Social Behavior, Vol. 50, pp. 261-276, September 2009.

[39] Q. Cheng, H. Li, , V. Silenzio, and E. D. Caine, "Suicide contagion: a systematic review of definitions and research utility," PLOS ONE, Vol. 9, pp. e108724, September 2014

[40] A. S. Mueller and S. Abrutyn, "Suicidal disclosures among friends: using social network data to understand suicide contagion," J. Health Social Behavior, Vol. 56, pp. 131-48, March 2015

[41] C. Haw, K. Hawton, C. Niedzwiedz, and S. Platt, "Suicide clusters: a review of risk factors and mechanisms," Suicide Life Threat Behavior, Vol. 43, pp. 97-108, February 2013

[42] Darmaningtyas, Pulung gantung: revealing the suicide tragedy in Gunungkidul (Pulung gantung: menyingkap tragedi bunuh diri di Gunungkidul), Yogyakarta: Salwa Press, 2002

[43] C. J. Pardede, "Karakteristik penderita percobaan bunuh diri dengan racun di RSUD Dr. Pirngadi Kota Medan Tahun 2006-2011 (Characteristics of suicide attempters by poison in RSUD Dr. Pirngadi Medan City in 2006-2011)," Jurnal Gizi, Kesehatan Reproduksi dan Epidemiologi, Vol. 1, pp. 1-10, 2012.

[44] A. Fahrudin, "Fenomena bunuh diri di Gunungkidul: catatan tersisa dari lapangan (suicide phenomenon in Gunungkidul: remaining notes from the case)," Jurnal Informasi, Vol.17, pp. 3-19, December 2012.

[45] J. B. Rotter, "Internal versus external control of reinforcement: A case history of a variable," American Psychologist, Vol. 45, pp. 489-493, April 1990. 
[46] M. O'Driscoll, Locus of control, In Jeffrey H. Greenhaus and Gerard A. Callanan, (Eds.), Encyclopedia of Career Development, 2006.

[47] H. Hendryadi, "Pengembangan skala locus of control (Developing locus of control scale)," Jurnal Riset Manajemen dan Bisnis (JRMB), Vol. 2, pp. 417-424, October 2017.

[48] I. Aydin, A. Algin, M. K. Poyraz, A. Kalenderoglu, "An analysis with Rotter Internal-External Locus of Control Scale, Rosenberg SelfEsteem Scale, and the Barratt Impulsivity Scale on patients who attempted to recurrent suicide," Eurasian Journal Emergency Medicine. Vol. 173, pp. 109-12, September 2018.

[49] H. Saied, M. H. Abdel Aal, and S. Mahmoud, "Relationship between locus of control and suicide attitude among adolescents commit suicide attempt," Journal of Nursing and Health Science. Vol. 7, pp. 86-99, March 2018

[50] I. W. Suwena, Bunuh diri: sesat penandaan pulung gantung di Gunungkidul (Suicide: misguided marking of pulung gantung in
Gunungkidul), Universitas Gadjah Mada, Yogyakarta, Unpublished Dessertation, 2016.

[51] S. Mihaljevic, B. Aukst-Margetic, B. Vuksan-Cusa, E. Koic, and M. Milosevic, "Hopelessness, suicidality and religious coping in Croatian war veterans with PTSD," Psychiatria Danubina, Vol. 24, pp. $292-$ 297, August 2012

[52] A. A. Ratnasari, "Analisis pemberitaan media pers terhadap kasus bunuh diri (Analysis of press coverage of suicides)," Proceedings the 3rd UGM Public Health Symposium, Vol. 34, May 2018.

[53] World Health Organization, Preventing suicide, Luxembourg: WHO, 2014

[54] M. Sisask and A.Värnik, "Media roles in suicide prevention: a systematic review," Int. J. Environ. Res. Public Health, Vol. 9, pp. 123-38, January 2012. 